\title{
Influenza or not influenza: Analysis of a case of high fever that happened 2000 years ago in Biblical time
}

\author{
Kam LE Hon ${ }^{*}$, Pak C Ng, Ting F Leung
}

\begin{abstract}
The Bible describes the case of a woman with high fever cured by our Lord Jesus Christ. Based on the information provided by the gospels of Mark, Matthew and Luke, the diagnosis and the possible etiology of the febrile illness is discussed. Infectious diseases continue to be a threat to humanity, and influenza has been with us since the dawn of human history. If the postulation is indeed correct, the woman with fever in the Bible is among one of the very early description of human influenza disease.

Infectious diseases continue to be a threat to humanity, and influenza has been with us since the dawn of human history. We analysed a case of high fever that happened 2000 years ago in Biblical time and discussed possible etiologies.
\end{abstract}

\section{Case}

The Bible descrbies the case of a woman with high fever cured by our Lord Jesus Christ. According to Mark 1:29 to 33 and Matthew 8:14-15, the mother-in-law of Simon Peter "lay sick" with a febrile illness [1]. When Jesus took her by the hand and lifted her up, the fever immediately left. The lady began to serve the household and probably prepared a meal. The case is also described in the gospel by Luke (Luke 4:38-39), who was a physician in his days and he specifically mentioned that the fever was high [1].

\section{Discussion}

What was the diagnosis of the febrile illness, based on the information provided by the gospels of Mark, Matthew and Luke [1]? It seems that the woman suffered an acute febrile illness with high fever and was sick enough to be bed-ridden. Luke did not quantify the fever as the Fahrenheit temperature scale was not invented until 1724 [2]. No other symptom or chronic illness was described in the three gospels. Possible etiology of her "acute febrile illness" is some sort of infection or inflammation. The Bible describes that when Jesus

\footnotetext{
* Correspondence: ehon@hotmail.com

Department of Paediatrics, The Chinese University of Hong Kong, Prince of Wales Hospital, Shatin, Hong Kong SAR, China
}

touched the woman, the fever retreated instantaneously. This implies that the disease was probably not a severe acute bacterial infection (such as septicemia) or subacute endocarditis that would not resolved instantaneously. It was probably not an autoimmune disease such as systemic lupus erythematousus with multiple organ system involvement, as the Bible does not mention any skin rash or other organ system involvement. The instantaneous cure also makes an underlying malignant etiology unlikely. It seems that an acute selflimiting infectious illness is a possible diagnosis. The brief duration, high fever, and abrupt cessation of fever makes influenza disease probable [3]. Shortly following her recovery, presumbly within minutes, it is described that the woman began to serve Jesus and the disciples, thus making influenza illness highly probable. Most miserably sick patients recover without sequlae when the high fevers subside following influenza-like illness [3].

The next question is whether the virus is influenza, avian flu, parainfluenza, or other respiratory viruses such as adenovirus or even SARS-CoV (Severe Acute Respiratory Syndrome-associated Coronavirus) [3-9]. Adenovirus and SARS-CoV are usually associated with pulmonitis, and the pulmonary symptoms may not resolve promptly [3-9]. It is unable to tell if the woman has been in contact with poultry or swine and contracted avian or swine influenza $[3,4]$. The Bible does 
not describe if any members of the family including Andrew and Simon developed febrile illness, before or subsequent to her febrile illness. The characteristic features of seasonal influenza include abrupt onset of fever, chills, non-productive cough, myalgias, headache, nasal congestion, sore throat, and fatigue. The diagnosis is mainly clinical. Seasonal influenza would be less likely if no members of the family were affected [3]. Avian influenza and other respiratory viruses may cause isolated infection without efficient human-to-human transmission. In any case, influenza-like illness due to a respiratroy virus would explain her symptomatology and clincial course [3]. Other possibilities include drug fever and poisoning (such as atropine). Naturally-occurring plants containing the belladonna alkaloid atropine could have been consumed but the Bible does not describe unusual food or medicine intake by the woman and her family. The other side effects of anticholinergic agent were absent. The woman would recover spontaneously when the effect of the offending substance wore off.

One final consideration that one might have is whether the illness was inflicted by a demon or devil. The Bible always tells if an illness is caused by a demon or devil (Matthew 9:18-25, 12:22, 9:32-33; Mark 1:23-26, 5:1-15, 9:17-29; Luke 4:33-35, 8:27-35, 9:38-43, 11:14) [1]. The victims often had what sounded like a convulsion when the demon was cast out. In our index case, demonic influence is not stated, and the woman had no apparent convulsion or residual symptomatology.

The Bible has many examples of descriptions of medical diseases. For instance, the first pediatric case of mouth-to-mouth cardiopulmonary resuscitation is vividly described in the Old Testament when the prophet Elisha pressed upon an apparently dead child and breathed into him seven times, and the child was revived (Kings 4:34-35) [1].

Influenza and respiratory viral infections have been documented throughout human history [3]. The current $2009 \mathrm{flu}$ pandemic is a global outbreak of a new strain of H1N1 influenza virus, often referred to colloquially as "swine flu" which began in the state of Veracruz, Mexico in April 2009 and the virus continued to spread globally. The World Health Organization (WHO) and US Centers for Disease Control (CDC) in June escalated the global alert level to phase 6 and declared the outbreak to be a global pandemic since the 1968 Hong Kong flu [4].

\section{Summary}

If the postulation is indeed correct, the woman with fever in the Bible is among one of the very early description of human influenza disease.

\section{Authors' contributions}

$\mathrm{KLH}$ conceived of the study, and was the principal author. TFL and PCN advised and reviewed the manuscript. All authors read and approved the final manuscript.

\section{Competing interests}

The authors declare that they have no competing interests.

Received: 16 June 2010 Accepted: 21 July 2010 Published: 21 July 2010

References

1. The Holy Bible, New King James Version. Nashville: Broadman \& Holman Publishers 1982.

2. Fahrenheit temperature scale. Sizes, Inc. 2006 [http://www.sizes.com/ units/temperature_Fahrenheit.htm], Retrieved February 1, 2010.

3. Hon KL, Leung AK: Severe childhood respiratory viral infections. Adv Pediatr 2009, 56:47-73.

4. Hon KL: Just like SARS. Pediatr Pulmonol 2009, 44:1048-9.

5. Hon KL, Leung CW, Cheng WT, Chan PK, Chu WC, Kwan YW, Li AM, Fong NC, Ng PC, Chiu MC, Li CK, Tam JS, Fok TF: Clinical presentations and outcome of severe acute respiratory syndrome in children. Lancet 2003, 361:1701-3.

6. Hon KL, Li AM, Cheng FW, Leung TF, Ng PC: Personal view of SARS: confusing definition, confusing diagnoses. Lancet 2003, 361:1984-5.

7. Leung TF, Wong GW, Hon KL, Fok TF: Severe acute respiratory syndrome (SARS) in children: epidemiology, presentation and management. Paediatr Resp Rev 2003, 4:334-9.

8. Li AM, Hon KL, Cheng WT, Ng PC, Chan FY, Li CK, Leung TF, Fok TF: Severe acute respiratory syndrome: 'SARS' or 'not SARS'. J Paediatr Child Health 2004, 40:63-5.

9. Hon KL, Leung E, Tang J, Chow CM, Leung TF, Cheung KL, Ng PC: Premorbid factors and outcome associated with respiratory virus infections in a pediatric intensive care unit. Pediatr Pulmonol 2008 43:275-80.

\section{doi:10.1186/1743-422X-7-169}

Cite this article as: Hon et al:: Influenza or not influenza: Analysis of a case of high fever that happened 2000 years ago in Biblical time. Virology Journal 2010 7:169.

\section{Submit your next manuscript to BioMed Central and take full advantage of: \\ - Convenient online submission \\ - Thorough peer review \\ - No space constraints or color figure charges \\ - Immediate publication on acceptance \\ - Inclusion in PubMed, CAS, Scopus and Google Scholar \\ - Research which is freely available for redistribution \\ Submit your manuscript at www.biomedcentral.com/submit}

